\title{
Environmentally Responsible Behavior Intentions of Wildlife Tourists Based on Recreational Involvement: A Case Study of Bird-Watching Tourists in Guangzhou
}

\author{
Lan Li \\ Jinan University, Guangzhou, Guangdong \\ Email: 786875366@qq.com
}

How to cite this paper: Li, L. (2018). Environmentally Responsible Behavior Intentions of Wildlife Tourists Based on Recreational Involvement: A Case Study of Bird-Watching Tourists in Guangzhou. Chinese Studies, 7, 95-113.

https://doi.org/10.4236/chnstd.2018.71009

Received: January 16, 2018

Accepted: February 25, 2018

Published: February 28, 2018

Copyright $\odot 2018$ by author and Scientific Research Publishing Inc. This work is licensed under the Creative Commons Attribution International License (CC BY 4.0).

http://creativecommons.org/licenses/by/4.0/

(c) (i) Open Access

\begin{abstract}
With the development of wildlife tourism, the negative influences of ecological environment and wildlife is increasingly becoming one of the concerns for many scholars. Moreover, wildlife tourists are the main body of tourism activities. Therefore, it is necessary to study the classification and market segmentation of wildlife tourists. Taking bird-watching tourists in Guangzhou as the research object, this study classified bird-watching tourists by recreation involvement, to compare and analyze the different types of tourists in the social demographic characteristics and environmental differences of responsible behavior intention. Research results: 1) through the K-means cluster analysis, bird-watching tourists can be divided into three different kinds of involvement, respectively "low risk tourists", "low attraction tourists" and "high involvement tourists", and through the chi-square test, it was found that different types of bird-watching tourists in two aspects of social demographic characteristics of gender and age had obvious differences, but on education, occupation and income distribution had no significant difference; 2) by LSD multiple comparison, this study found that average scores of environmentally responsible behavior intentions of high involvement type were significantly higher than the other two classes, which means that bird-watching tourists were involved in birding tourism activities deeper, and their environmentally responsible behavior intentions are stronger; 3) By k-means clustering analysis, it was found that low risk and low attraction tourists had similar average score, but their willingness in environmentally friendly behaviors existed significant differences by LSD test. On this basis, the development strategy of wildlife tourism is put forward, the wildlife tourists behavior research is strengthened, the wildlife tourism market is cultivated, and the segmentation
\end{abstract}


and characteristics of the target market are provided.

\section{Keywords}

Recreational Involvement, Wildlife Tourists, Environmentally Responsible

Behavior Intentions, Bird-Watching Tourists in Guangzhou

\section{Introduction}

What is the core attraction of wildlife tourism is the wild animal. According to the research of Duffus and Dearden (1990), it can be divided into three types based on the point of view of wildlife resource consumption. Firstly, it is the consumption of wildlife tourism, in which traveling and leisure activities of people will lead to purpose or permanent damage of wild animals and their habitats, such as hunting and fishing. The second type of wildlife tourism is the semi-consumption, and one of the typical representative samples is the zoo. The third one is non-consumption, referring to just watching wildlife, such as watching birds and sea whale, which don't reduce the amount of wildlife resources. Among them, the non-consumption of wild animals, conforming to the principles of sustainable development and green tourism, is developing rapidly around the world. In fact, it will involve different levels of consumption in infrastructures, wildlife and their habitats in any form of wildlife tourism. However, comparing to other types of travel, non-consuming wildlife tourism has a more serious negative impact on the potential environment. Thus, we should pay more attention to its development. In China, there are many problems in the process of non-consuming wildlife tourism, and these problems directly cause a big gap between non-consuming wildlife tourism development and the essential requirement of it. First of all, the tourist area of the development of the wildlife tourism is often ecological sensitive area; the main attractions of it are wild animals. What's the most important thing is that most of these wild animals are endangered animals, such as the giant panda. So carrying out such activities can produce different degree of interference of wild animals. Secondly, the rapid growth of tourist' numbers and the loss of tourists' behavior pose a threat to wildlife and its living environment.

The sustainable development of non-consuming wildlife tourism depends not only on the government, but also on the environmental attitudes and behaviors of tourists. On the whole, non-consuming wildlife tourists have higher environmental awareness, participation in environment and wildlife protection than average tourists (Rawles \& Parsons, 2004). However, further studies have found that there are strict market segments for wildlife tourism, and different types of tourists have different demographic characteristics, psychological needs and tourism behaviors (Lemelin \& Smale, 2006). Therefore, it is necessary to study the classification and market segmentation of wildlife tourists. Studies have been 
conducted on the classification of wildlife tourists from the perspective of tourists' participation level, tourism motivation and knowledge level of wildlife. However, the empirical study on the classification of wildlife tourists from the perspective of recreation involvement has been rare so far. In addition, a number of studies have shown that recreational involvement has a positive impact on environmentally responsible behavior intentions, but there is a lack of discussion on wildlife tourists. Therefore, in view of the shortcomings of domestic research, this study uses involvement theory as theoretical basis of research, taking bird-watching tourists in Guangzhou as the research object, to compare and analyze the social demographic characteristics and the differences of environmental responsible behavior intention of different types of tourists with different levels of involvement, to have a deeper understanding of wildlife tourists' psychological and behavior characteristics, make up the lack of domestic research on recreation involvement, and provide guidance and advice for the local community, nature reserve management department, and the development of ecological tourism operators to better guide tourists' environmental responsible behavior.

Generally speaking, the article structure of this study can be divided into the following parts: firstly, the questionnaire study was conducted to study visitor's recreation involvement, environmental responsibility, behavioral intention and demographic characteristics. And then using the theory of involvement and SPSS22.0 software to carry out the factor analysis of recreation involvement, K-Means clustering analysis of bird-watching tourists in accordance with the recreation involvement, and use the single factor analysis of variance (ANOVA) to explore the relationship between recreation involvement and environment responsible behavior intention. Finally, based on the analysis of data results, the conclusions and implications are drawn.

\section{Theoretical Basis}

\subsection{Wildlife Tourism}

Wildlife tourism is one kind of niche tourism, which mainly attractions are natural resources, especially wild animals. Since the 1980's, with more and more people realize the importance of the relationship between man and nature, people's nature and environmental protection consciousness have also improved, the non-consuming wildlife tourism, having small impact on the environment but meeting the demand of interactive activities between people and animals, has become more and more popular around the world. Moreover, from the point of long-term development, this kind of tourist activities is beneficial to solve the contradiction between economic development and wildlife protection (Cong, Wu, \& Li, 2012).

As the main body of wildlife tourism, behavior and characteristics of wildlife tourist have important influence on wildlife tourism, animals and their living environment, and other aspects, so foreign scholars have focused on researches 
of wildlife tourists for a long time. Besides, people subconsciously think wildlife tourists are environmentally friendly, who will have a strong awareness of wildlife protection, but in fact, some wild animals tourists often bring unintended harm to animals. In addition, not all wildlife tourism operators have a strong sense of environmental protection (Lubeck \& Kusler, 1990). Therefore, it is widely believed that it is necessary to carry out strict market segmentation research on wild animal tourists. According to existing research results, scholars tried to classify wildlife tourists by tourists participation (Ballantyne et al., 2010), tourist motives (Beh \& Bruyere, 2007), the knowledge level of wildlife (Duffus \& Dearden, 1990) to discuss the differences of demographic characteristics, travel motivation as well as the impact on wildlife and their environment. Similar to foreign scholars, many scholars in China are concerned about the study of wildlife tourists. For example, based on Bryan's leisure classification, Li Yanqin, Cai Yunlong (2004) divided the eco-tourists of Beijing baihua mountain into three categories: strict, regular and occasional; according to the different three factors of activity included levels of the bird-watching tourists technology, participating in the frequent degree and the loyalty, the bird-watching tourists in Beijing can be divided into four types, respectively are common bird-watching tourists, occasional bird-watching tourists, active bird-watching tourists and skilled birdwatching tourists (Li et al., 2009). At the same time, domestic scholars have also used questionnaire to investigate the characteristics and the destination preference attributes of bird-watching tourists, to provide operators with segmentation and the characteristics of the target market.

\subsection{Recreation Involvement}

In the field of western consumer behavior research, involvement is an important theory to explain consumption behavior, which is proved to be one of the most important determinants of consumption behavior. In the 1880s, it was introduced by Selin and Howard (1988) in the field of leisure and recreation. Selin \& Howard (1988) believes that recreational involvement is the level of pleasure and self-expression that individuals acquire when they participate in a recreational activity. However, in terms of leisure and recreation, most scholars adopted or borrowed the definition of leisure involvement from Havitz and Dimanche (1997). Havitz and Dimanche (1997) argues that it is a state of people's feeling or interest related products, in a certain time point, this state will be reflected in importance, value, symbolic value, risk probability elements such as perception, and also will be affected by certain stimulus or situation, which can driver behavior.

Because the definition of recreation involvement presents multiple meanings, so there are many views on the dimension and measurement of recreation involvement. In the early days, scholars generally believed that the involvement was Single dimension, and among them, the representative scale was the PII scale proposed by Zaichkowsky (1985). This scale is a kind of single dimension 
of personal involvement scale, to divide involvement into three different levels, included high, medium and low. it is suitable for measuring the degree of consumer involvement in products associated with low price, low risk or having low relationship with them. Since 1985, Laurent and Kapferer (1985) have put forward Consumer Involvement scale (Consumer Involvement Profile, CIP) including pleasure, importance, symbolic, risk possibility and risk consequences. And the point of view that involvement is a multidimensional structure was adopted by more and more consumer behavior and leisure researches' scholars. When the CIP scale was introduced into the special situation of leisure tourism, some scholars eliminated the risk dimension. For example, the CIP scale was used for leisure research in McIntyre and Pigram's research (1992), but only three leisure involvement dimensions were found: attractiveness, self-expression and core lifestyle. Due to the difference between tourist activities which tourists should leave their daily residences and leisure activities which mainly happen in the place of residence, the decision-making of tourism is considered to be a high-involvement decision (Havitz \& Dimanche, 1997), which contains more risk factors. In the research of the relationship among tourists' involvement, place attachment and interpretation satisfaction in Taiwan's national parks, Hwang et al. (2005) used four dimensions, respectively, are importance and entertainment, self-expression and symbolic value, risk possibility and risk consequences to measure tourists involvement. The internal consistency check showed that tourists involvement scale had high reliability (alpha $=0.9026)$. On the basis of previous studies, this study suggests that recreation involvement is a potential motivation or interest in a tourist activity. At the same time, combining with the particularity of non-consuming wildlife tourism, this study will use the research of Laurent and Kapferer's CIP scale and Hwang et al. (2005) to measure the participation of recreation.

It has been proved that leisure involvement is an effective variable for market segmentation. Christine and Bharath (1995) used Zaichowsky's single dimension PII scale, to divide college students into three groups, by the degree of college students travel decisions within winter vacation, and found that there are significant differences between groups in tourism destination choice. On the basis of Laurent and Kapferer proposed CIP scale, Minkyung Park et al. (2002) separated gambling tourists into low involvement group, high centricity gambling involvement group, high entertaining gambling involvement group and high self-expression gambling involvement group. The results showed that there was no significant difference in behavioral characteristics, demographic characteristics and behavioral intentions, but there were significant differences in destination perception.

There are relatively rich researches in domestic and overseas about market segmentation based on recreation involvement, but few researches take leisure involvement as variable subdivision of tourism market in China, among them the representative research is Zhang Hongmei and Liu Lin's research. Zhang 
Hongmei and Lu Lin scholars (2010) conducted cluster analysis by tourists' involvement in inbound tourists of Guilin and Yangshuo, and compared the characteristics and attitudes of different types of tourists. Cluster analysis classified inbound tourists into four types: moderate involvement, low involvement, high involvement and low risk. These types of tourists had not significant difference in social demographic characteristics and behavior characteristics, but had big difference in the cultural group, the number of information sources, host communication preferences, the overall image of destination and satisfaction. These studies mainly subdivided domestic tourists in specific research situations, which cannot be used to other tourists and other situations without verification. So in this paper, in reference on the basis of predecessors' research and scientific analysis of leisure involvement, the author launched systematically and in-depth market segmentation research of bird-watching tourists, to provide the basis suggestions for targeted marketing.

\subsection{Environmentally Responsible Behavior Intentions}

Currently, even though there are many definitions about environmentally friendly behaviors, such as environment responsible behavior, environmental behavior and environmental friendly behavior, their basic connotations are consistent. It is refers to people use various means to protect the environment and show environmentally friendly behavior in practice. Based on this study, the author discusses the psychological and behavioral characteristics of tourists with different levels of involvement, so this paper adopts the word "responsible behavior" from social psychology. Kollmuss and Agyeman (2002) summarized environmental responsible behavior as "the act of minimizing the negative impact of the environment by individuals or groups". Later, Chiu et al. (2014) defined the responsible behavior of environment in the tourism context based on summarizing relevant researches. They pointed out that environmental responsible behavior is “tourists' series of behavior in leisure activities, are conducted to reduce environmental negative impacts and promote environmental protection".

Empirical studies have shown that recreational involvement has a positive impact on environmentally responsible behavior. According to the degree of tourists' involvement of the environmental protection practice in the resort, Lee and Moscardo (2005) made a detailed comparison of tourists having the same ecological accommodation experience. The results showed that higher involvement degree of visitors will pay more attention to the negative impact of tourism activities on the ecological environment. In order to explore relationship between leisure involvement and environmental friendly behavior, Thapa et al. (2008) took outdoor leisure activities' visitors as research objects and found that recreation involvement and environmental friendly behavior has a significant positive correlation, and recreation involvement is an important factor to understand environmental friendly behavior. Chiu et al. (2014) took the eighth of China's Taiwan region "national park" which is Taijiang park as an example, to 
discuss the relationship of perceived value, satisfaction of tourists, ecotourism involvement, and environmental friendly behavior intention, and found that tourists' recreation involvement has a significant positive and also an indirect intermediary effect on environment friendly behavior.

In China, the relationship between recreational involvement and environmental behavior has gradually attracted the attention of researchers, but relevant research literatures are still rare. Zhang Anmin and Li Yongwen (2016), and Liu Jingyan et al. (2009) confirmed that there is a positive correlation between recreational involvement and environmental responsible behavior. Generally speaking, existing researches at home and abroad, however, usually take recreation involvement as an influencing factor of environmental responsible behavior, there is few study examine environment responsible behavior separately from the perspectives of recreation involvement. This article explores the relationship between leisure involvement and environment friendly behavior, to enhance the level of our country's tourist environment education and promote the participation of tourists in environmental friendly behavior.

\section{Methodology}

\subsection{Study Site}

Guangzhou Nansha wetland park, located in the most southern of Guangzhou city, being the largest wetland park in Guangzhou city, is one of the three paths of migratory birds in our country, namely the eastern migratory path and the richest and most concentrated of migratory birds in Guangzhou area. There are abundant bird resources in Nansha wetland, according to related statistics, its bird resources accounted for about $42.0 \%$ of the country's 81 families, $8.01 \%$ of 1186 species. Among them, winter or summer birds have 42 species, accounting for $44.2 \%$ of the total species. What's more, 48 species of resident birds, accounting for $50.5 \%$ of the total number of species. Furthermore, Summer migratory birds are 5 species, accounting for $5.3 \%$ of the total number of species. Besides, there are more than 10,000 species of ducks, herons, gulls and cormorants. Among them, there are 11 species belong to treasure birds under national protection, and 16 species of endangered species in international convention.

Up to now, Nansha wetland, experienced two phase of construction, has become an ecological tourism and leisure area with a set of comprehensive facilities, such as ecological sightseeing, science education, movie and television culture and leisure and health. It is known as the paradise of migratory birds, attracted a large number of tourists and scientific workers to carry out bird-watching tourism and scientific research activities. Because wetland bird tourism activities are aimed to don't influence and change the life of birds and their habitats, so bird-watching tourism is one of the typical non-consumption wildlife tourism.

There are two main reasons why this paper choose Nansha wetland park as a case study. Firstly, because the author has become one of members of Flight Feathers, a famous volunteer teams in Guangzhou, and one of bird-watching 
tour guides for many years. The author not only participated in Nansha wetland birding tours with members, but also organized birding tours for tourists from primary and secondary schools in guangzhou, xinhua study education institutions and flight feathers team, so the author can make questionnaires and classification on these tourists smoothly. Secondly, its geographical location is superior because of less than two hours' drive, tourists can arrive the downtown of Guangzhou. Thirdly, Nansha wetland, a paradise for birds, having excellent experiences of tourism products, is a typical wild habitat which is not only greatly facilitates wildlife tourism activities, but also good for examining the environmental friendly behavior of tourists.

\subsection{Questionnaire Design}

The questionnaire of this study consists of 3 parts. The first part is the birdwatching tourists' recreation involvement, this study makes references from Laurent and Kapferer (1985), McIntyre and Pigram (1992) and Hwang et al (1999), and combines the characteristics of bird-watching tourism, to design five dimensions of recreation involvement, including importance, pleasure, symbolic, risk possibility and risk results, with a total of 15 items; The second part uses the scale of studies of Chiu et al. (2014), Lee (2011), and Li Qiucheng, Zhou Lingqiang (2014) based on the bird-watching tourism specific situation, to extract seven multi-items as tourists' environmental responsible behavior intention, of which environment maintenance activities includes four items, promoting environment behavior have three items. The form of involvement and environmental friendly behavior intention's items are adopted by the five point likert scale, "1" means "strongly agree", " 5 " means "strongly disagree”. The operational definition and measurement scales of the research variables are shown in $\mathrm{Ta}$ ble 1. The third part is the demographic characteristics of tourists, including gender, age, occupation, monthly income and educational background. To improve the reliability and validity of research, the corresponding variable items of this study are from the previous literature, and in combination with the proper changes of bird-watching tourism situation, to make a preliminary questionnaire. Then the author selects ten senior bird friends for interview and pre-survey. The questionnaire was further modified with the feedback of senior birdwatching tourists, to determine the final questionnaire.

\subsection{Data Collection and Analysis}

The collection of this study's data taking author's friends of bird-watching tour group as investigation objects, was conducted from February, 2016 to March, 2016 , through issuing onsite or online questionnaires, and in-depth interviews and participatory observation. A total of 450 questionnaires were issued and 443 were recovered. The incomplete and less authentic questionnaires were deleted, and 392 valid questionnaires were obtained. The effective questionnaire rate was about $88.5 \%$. This study analyzed questionnaires by SPSS22.0. The data processing was mainly divided into three steps: 1) Analyzing recreation 
Table 1. The operational definition and measurement scales of research variables.

\begin{tabular}{|c|c|c|}
\hline Variable & Operability defines & Measurement scale \\
\hline Importance & $\begin{array}{l}\text { Individuals are aware of the importance of } \\
\text { attending bird-watching tour. }\end{array}$ & \\
\hline Pleasurable & $\begin{array}{l}\text { Bird-watching tour bring the pleasure and } \\
\text { happiness to tourists. }\end{array}$ & \\
\hline symbolic & $\begin{array}{l}\text { The individual would like to show individual } \\
\text { skills or be one of the group, and express } \\
\text { themselves through the participation of } \\
\text { bird-watching tour. }\end{array}$ & $\begin{array}{l}\text { making references from } \\
\text { Laurent and Kapferer } \\
\text { (1985), McIntyre and } \\
\text { Pigram (1992) and Hwang } \\
\text { et al. (1999), }\end{array}$ \\
\hline Risk probability & $\begin{array}{l}\text { It refers to the perception that tourists are faced } \\
\text { with the risk and uncertainty when they choose } \\
\text { bird travel products. }\end{array}$ & $\begin{array}{l}\text { and combines the } \\
\text { characteristics of } \\
\text { bird-watching tourism }\end{array}$ \\
\hline Risk consequences & $\begin{array}{l}\text { It refers to the perception of the degree of } \\
\text { negative experience are caused by the improper } \\
\text { selection of bird-watching tourism products or } \\
\text { destinations. }\end{array}$ & \\
\hline $\begin{array}{l}\text { Environmental } \\
\text { maintenance behavioral } \\
\text { intention }\end{array}$ & $\begin{array}{l}\text { In the process of tourism, tourists' intention of } \\
\text { taking action to reduce the negative impact on } \\
\text { the scenic spot environment. }\end{array}$ & $\begin{array}{l}\text { Using the scale of studies of } \\
\text { Chiu et al. (2014), Lee } \\
\text { (2011), and Li Qiucheng, }\end{array}$ \\
\hline $\begin{array}{l}\text { Promoting environment } \\
\text { behavioral intention. }\end{array}$ & $\begin{array}{l}\text { Tourists initiatively take action to promote } \\
\text { environmental protection in scenic spots. }\end{array}$ & $\begin{array}{l}\text { Zhou Lingqiang (2014) and } \\
\text { based on the bird-watching } \\
\text { tourism specific situation }\end{array}$ \\
\hline
\end{tabular}

involvement by factor analysis, extracting the factor, which characteristic value is greater than 1 through principal component analysis and standardization of orthogonal rotation, and screening criteria eliminate variables by the load is lower than 0.40 ,which was more conducive to the next step of recreation involvement classification.; 2) Using k-means q-mode cluster analysis method to classify tourists with recreation involvement; 3) In order to compare the demographic characteristics of different types of bird-watching tourists, the chi-square test was conducted according to the clustering analysis results. 4) In order to show more clearly the impact of recreation involvement on environmentally responsible behavior intentions, a single factor variance analysis (ANOVA) was used to explore the differences in the environmentally behavioral intention of tourists. The internal consistency coefficient (Cronbach's) of recreation involvement and environmentally responsible behavior intentions respectively are 0.772 and 0.831 , and two of scales' reliabilities are acceptable.

\section{Data Analysis Results}

\subsection{Cluster Analysis of Bird-Watching Tourists Based on Recreation Involvement}

\subsubsection{Factor Analysis}

The KMO statistical analysis and Bartlett sphere test were performed on 15 variables of recreation involvement, and the value was 3340.417 ( $\mathrm{df}=105, \mathrm{p}=$ 0.000 ), and $\mathrm{KMO}$ was 0.856 , indicating that the variable was suitable for factor analysis. The results showed that the maximum load of the variable "whenever I 
buy bird-watching tourism products, I can't really know whether this is should buy" is $0.367<0.5$, the maximum load of the variable of "choose birding tourism product destination is very troublesome" is $0.105<0.5$, so they were eliminated.

The remaining 13 variables were analyzed by principal component analysis and variance maximum orthogonal rotation method, and the results were shown in Table 2. The value of $\chi^{2}$ of the butler sphere test is 3152.935 ( $\left.\mathrm{df}=78\right), \mathrm{p}=$ 0.000 , and the KMO statistical value is 0.843 , indicating it is appropriate for making factor analysis. Results were extracted four factors (Table 2), according to general characters of factors 1 to 4 , these factors respectively named attraction, symbolic, risk possibility and risk consequences. Among them, according to McIntyre and Pigram (1992), attraction refers to the degree of pleasure and the importance of recreation in leisure activities. So, combining factors of "importance" and "pleasure" into one, and calling it as "attraction".

Table 2. Results of factor analysis of bird-watching tourists' recreation involvement.

\begin{tabular}{|c|c|c|c|c|c|}
\hline \multicolumn{6}{|c|}{ Rotation component matrix } \\
\hline \multirow{2}{*}{ Observation variable } & \multicolumn{4}{|c|}{ Factor } & \multirow{2}{*}{$\begin{array}{l}\text { The names } \\
\text { of factors }\end{array}$} \\
\hline & 1 & 2 & 3 & 4 & \\
\hline Bird-watching tourism is very important to me. & .908 & & & & \\
\hline $\begin{array}{l}\text { Bird-watching tourism is one of the most } \\
\text { enjoyable activities for me }\end{array}$ & .893 & & & & \\
\hline $\begin{array}{c}\text { Comparing to others means of traveling, I prefer } \\
\text { bird-watching tourism }\end{array}$ & .891 & & & & Attraction \\
\hline $\begin{array}{l}\text { Bird-watching tourism is a very satisfying activity } \\
\text { for me }\end{array}$ & .877 & & & & \\
\hline Bird-watching tourism brings me a lot of fun & .789 & & & & \\
\hline Bird-watching tourism is fun and enjoyable & .661 & & & & \\
\hline $\begin{array}{l}\text { Bird-watching tourism can reveal what kind of } \\
\text { person am I }\end{array}$ & & .914 & & & \\
\hline $\begin{array}{l}\text { I know a lot of knowledge about } \\
\text { bird-watching tourism }\end{array}$ & & .901 & & & Symbolic \\
\hline $\begin{array}{l}\text { When I was involved in bird-watching } \\
\text { tourism, I was happy to let it be known }\end{array}$ & & .826 & & & \\
\hline $\begin{array}{l}\text { When I bought bird-watching products, I was } \\
\text { always unsure of my options }\end{array}$ & & & $\begin{array}{l}.872 \\
.855\end{array}$ & & $\begin{array}{l}\text { Risk } \\
\text { probability }\end{array}$ \\
\hline $\begin{array}{l}\text { I would be very sad if my choice proved to be a } \\
\text { failure after going to bird-watching }\end{array}$ & & & & .875 & Risk \\
\hline $\begin{array}{l}\text { Choosing unsuitable bird-watching products can } \\
\text { be annoying }\end{array}$ & & & & .536 & consequences \\
\hline Characteristic root & 4.325 & 2.587 & 1.842 & 1.205 & \\
\hline Explained variance (\%) & 33.271 & 19.897 & 14.166 & 9.266 & \\
\hline Accumulated variance & 33.271 & 53.168 & 67.335 & 76.600 & \\
\hline
\end{tabular}

Note: extraction method: principal component rotation method; the orthogonal rotation method with Kaiser standardization; Rotation is conversed after 5 iterations. 


\subsubsection{The Cluster Analysis of Bird-Watching Tourists Based on Recreation Involvement}

The cluster analysis was carried out by using four leisure involvement factors as cluster variables to find the market with similar degree of involvement. The kmeans clustering method were used respectively for the calculations of two classification scheme, three classification scheme, four classification scheme, and five classification scheme. And the initial class center was determined by SPSS. What's more, the convergence criteria was set to $2 \%$, namely when the maximum of center distance change (Euclidean distance) was less than the minimum of $2 \%$ of the initial class center coordinates, it needed to stop the iteration. Compared with several classification schemes, it was found that three types of results were ideal and the distribution of tourists was more reasonable (Table 3). The specific characteristics of each type of tourist were explained as follows:

As for the first type of tourists, comparing to others, in addition to having higher score of attractive factors, its scores of other factors were lower than the other two groups, and scored significantly lower on risk factors than the other two categories. It showed that tourists of this type are more concerned about the attraction of bird-watching tourism, and may not pay much attention on risks caused by participating in bird-watching tours. So this type was named "low-risk probability" $(\mathrm{n}=108)$.

For second type of tourists, their scores of symbolic, risk possibility and risk consequences are all in the medium level, but on the attractive factors, the score is only 2.51 , so they were named "low attraction type" $(\mathrm{n}=154)$. It can be seen that such tourists have reached a certain degree of involvement in bird-watching tourism, but bird watching-tourism has not brought them great attraction. This is also in line with reality. In the process of participatory observation, because bird-watching tourism is one kind of outdoor activities, and most of the time tourists go to the place where hasn't been developed or the development of it is not mature, although a lot of parents don't like bird-watching, they would like to cultivate their children's interest in bird-watching, so they still choose to accompany their children to participate in bird-watching tourism. In addition, many bird-watchers are not focused on birds, their main purpose is taking beautiful pictures.

The average of four factors of the third kind of tourists were higher than others. It illustrated tourists showed higher attention and involvement on birdwatching, so they were named "high involvement tourists" $(n=130)$.

Table 3. Results of cluster analysis of recreation involvement for bird-watching tourists.

\begin{tabular}{cccccc}
\hline $\begin{array}{c}\text { Recreation } \\
\text { involvement }\end{array}$ & $\begin{array}{c}\text { Category 1: } \\
\text { Low risk probability } \\
(\mathbf{n}=\mathbf{1 0 8})\end{array}$ & $\begin{array}{c}\text { Category 2: } \\
\text { Low attractive } \\
(\mathbf{n}=\mathbf{1 5 4})\end{array}$ & $\begin{array}{c}\text { Category 3: } \\
\text { High involvement } \\
(\mathbf{n}=\mathbf{1 3 0})\end{array}$ & F value & p value \\
\hline Symbolic & 3.15 & 3.34 & 4.44 & 126.021 & 0.000 \\
Risk consequences & 3.95 & 4.38 & 4.46 & 15.808 & 0.000 \\
Attraction & 3.91 & 2.51 & 4.08 & 242.968 & 0.000 \\
Risk probability & $\mathbf{2 . 8 1}$ & 3.77 & 4.44 & 173.388 & 0.000 \\
\hline
\end{tabular}




\subsection{Comparison of Three Types of Bird-Watching Tourists}

\subsubsection{Comparison of Demographic Characteristics}

In order to reveal the demographic characteristics of different types of birdwatching tourists, the chi-square test was conducted according to the clustering analysis results, and the results were shown in Table 4. According to the results in Table 4, in terms of demographic characteristics, three types of tourist only exist big differences in gender and age, and no significant difference in the other three variables (education, occupation and monthly income). Specifically, there were more women than men in three categories, while the number of women of low attractiveness and high involvement was 2 - 3 times higher than men, showing a significant difference. This is consistent with the findings of Zeng

Table 4. Demographic characteristics of bird-watching tourists.

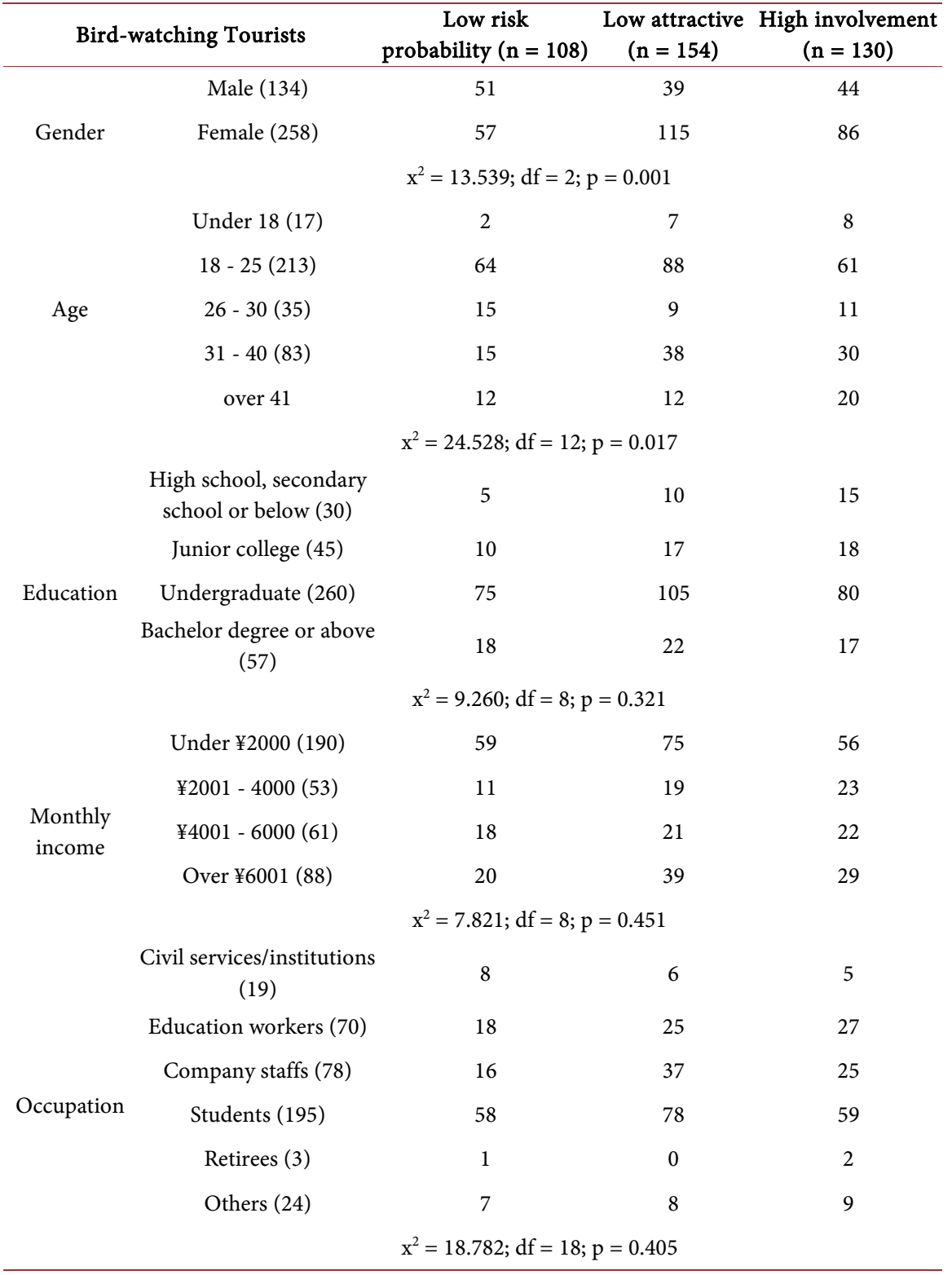


Feifei et al. (2014). Moreover, the women' proportion of low-attractiveness was significantly higher than those of the other two types. According to the data of Table 3, the perceived risk factor perception of low-attractiveness tourists is relatively high, suggesting that women are more focused on the involved risk of bird-watching tourism, and less emphasis on the pleasure of bird-watching tourism. However, the proportion of men in low risk type is high, related to women are more inclined to the pursuit of a sense of security, while men prefer adventure activities. It can be seen that gender is one of the most important criteria in dividing bird-watching tourists.

In terms of age, $54.3 \%$ of people are aged 18 to 25 years old, it would seem that young people are the main force of Guangzhou bird-watching tourists group. This is in line with actual development background of bird-watching tourism in our country. In our country, due to the development history of ecological bird-watching tourism is not long, most of bird-watching tourists are environmentalists, and many bird-watching activities are launched by college students. The another part of ecological bird-watching tourists' age are 26 to 40 years old, who usually have table job and high economic income, living tense and busy, so they want to escape from daily life, return to nature, loosen body and mind. For the elderly, due to physical concerns and psychological conservatism, their needs of participating in bird-atching tourism is low.

In the survey, it is found that the tourist education of bird-watching tourism is generally high. The majority of tourists with bachelor's degree or above (80.9\%), but only $7.7 \%$ are high school and secondary school students. Besides, there is also a significant feature in the structure of educational qualifications. It is that the high academic experience is clearly concentrated in the low attractiveness type. According to the in-depth interview, many interviewees are biological or related majors. Li, from the school of life sciences at south China normal university, told the author that the reason why he took part in bird-watching tourism was to complete his homework. A lots other interviewees told the author that they were motivated by a sense of social responsibility, and then choseed to watch birds, to popularize knowledge of birds with others.

Finally, according to the two factors of monthly income and occupation, as many of the respondents were students (49.7\%), the monthly income reached $48.4 \%$ in $¥ 2000$ and below. However, the proportion of $¥ 4001$ and above is $38 \%$, which indicates that there is still a large proportion of middle and high income earners. It is probably because bird-watching tourism is a leisure tourism with high input, high cost of travel and equipment, this requires bird-watching tourists generally have higher economic income. In addition, in terms of career, $47.4 \%$ of employees are low attraction type tourists, this may be related to office worker, who want to escape from the city life by participating.

\subsubsection{The Differences Environmentally Responsible Behavior Intentions of Tourists with Different Levels of Recreation Involvement}

One-way ANOVA was used to explore the differences environmentally respon- 
sible behavior intentions of tourists with different levels of recreation involvement. If a single factor analysis of variance was found that the difference reached a significant level, then the LSD test method was further used to analyze the differences among different groups. The results are shown in Table 5.

On the whole, there were significant statistical differences among the seven subjects that measured environmentally responsible behavior intentions of birdwatching tourists in three different levels of recreation involvement. Through

Table 5. Pro-environmental behavior intention difference of different recreation involvement bird-watching tourists.

\begin{tabular}{|c|c|c|c|c|c|c|c|c|}
\hline \multirow{3}{*}{ Variable } & \multicolumn{3}{|c|}{ Bird-watching Tourists } & \multirow{2}{*}{\multicolumn{3}{|c|}{$\begin{array}{l}\text { LSD multiple } \\
\text { comparison }\end{array}$}} & \multirow{3}{*}{ F value } & \multirow{3}{*}{$P$ value } \\
\hline & \multirow{2}{*}{$\begin{array}{c}\text { Low risk } \\
\text { probability (1) }\end{array}$} & \multirow{2}{*}{$\begin{array}{c}\text { Low } \\
\text { attractive (2) }\end{array}$} & \multirow{2}{*}{$\begin{array}{c}\text { High } \\
\text { involvement (3) }\end{array}$} & & & & & \\
\hline & & & & Touri & ype & significant & & \\
\hline & & & & 1 & 2 & 0.064 & & \\
\hline $\begin{array}{l}\text { Factor 1: environmental } \\
\text { maintenance behavioral intention }\end{array}$ & 4.44 & 4.31 & 4.82 & 1 & 3 & 0.000 & 30.571 & 0.000 \\
\hline & & & & 3 & 2 & 0.000 & & \\
\hline I will learn the & & & & 1 & 2 & 0.04 & & \\
\hline knowledge of protecting birds and & 4.50 & 4.23 & 4.84 & 1 & 3 & 0.01 & 23.110 & 0.000 \\
\hline their nabitats. & & & & 3 & 2 & 0.00 & & \\
\hline I will remind tourists around me not & & & & 1 & 2 & 0.331 & & \\
\hline $\begin{array}{l}\text { to do anything that affects the } \\
\text { normal activities of birds and their }\end{array}$ & 4.26 & 4.35 & 4.75 & 1 & 3 & 0.000 & 15.546 & 0.000 \\
\hline habitats & & & & 3 & 2 & 0.000 & & \\
\hline I try not to disturb the birds and the & & & & 1 & 2 & 0.022 & & \\
\hline habitat of the birds during the & 4.56 & 4.36 & 4.8 & 1 & 3 & 0.020 & 17.360 & 0.000 \\
\hline bird-watching tour & & & & 3 & 2 & 0.000 & & \\
\hline & & & & 1 & 2 & 0.708 & & \\
\hline $\begin{array}{l}\text { Factor 2: promoting environment } \\
\text { behavioral intention }\end{array}$ & 3.72 & 3.76 & 4.43 & 1 & 3 & 0.000 & 45.143 & 0.000 \\
\hline & & & & 3 & 2 & 0.000 & & \\
\hline I will participate in & & & & 1 & 2 & 0.080 & & \\
\hline $\begin{array}{l}\text { voluntary activities to maintain and } \\
\text { promote the environmental }\end{array}$ & 4.14 & 3.93 & 4.67 & 1 & 3 & 0.000 & 21.965 & 0.000 \\
\hline quality of scenic spots & & & & 3 & 2 & 0.000 & & \\
\hline I will report to the & & & & 1 & 2 & 0.358 & & \\
\hline $\begin{array}{c}\text { management about } \\
\text { issues and opinions of protecting }\end{array}$ & 3.53 & 3.42 & 4.41 & 1 & 3 & 0.000 & 46.446 & 0.000 \\
\hline environment & & & & 3 & 2 & 0.000 & & \\
\hline & & & & 1 & 2 & 0.015 & & \\
\hline $\begin{array}{l}\text { I will donate money to support the } \\
\text { ecological environment protection }\end{array}$ & 3.30 & 3.60 & 4.11 & 1 & 3 & 0.000 & 20.339 & 0.000 \\
\hline & & & & 3 & 2 & 0.000 & & \\
\hline If there is a public & & & & 1 & 2 & 0.202 & & \\
\hline $\begin{array}{l}\text { welfare project with environmental } \\
\text { protection theme, I will spend time }\end{array}$ & 3.94 & 4.07 & 4.55 & 1 & 3 & 0.000 & 18.268 & 0.000 \\
\hline on it & & & & 3 & 2 & 0.000 & & \\
\hline
\end{tabular}


multiple comparisons of LSD, it was found that there were significant differences between high-involvement tourists and the others two types of tourists in all projects. After comparing the mean value, the mean values of high-involvement tourists were significantly higher than those of the other two groups $(\mathrm{p}=0.000<$ 0.050). This partly explains that bird-watching tourists involve in bird-watching deeper, they will have stronger willingness of implementing environmentally responsible behavior. It is consistent with the results of Thapa (2008), Lee (2011) and Chiu (2014), and other scholars. But comparing the differences of the low risk and low attraction tourists, there are only significant differences in four items, respectively are "I will learn the knowledge of protecting birds and their habitats. "( $p=0.040<0.050)$," I try not to disturb the birds and the habitat of the birds during the bird-watching tour" $(\mathrm{p}=0.022<0.050)$, "If there is a public welfare project with environmental protection theme, I will spend time on it" $(\mathrm{p}=0.080<0.050)$, "I will donate money to support the ecological environment protection" $(\mathrm{p}=0.015<0.050)$. On the contrary, there is no significant difference in the remaining items.

By means of comparative analysis, the low risk bird-watching tourists' mean value in "I'll go to learn the knowledge of protecting birds and their habitats", "I try not to disturb the birds and the habitat of the birds during the bird-watching tour" and "If there is a public welfare project with environmental protection theme, I will spend time on it" successively are: $4.5,4.56,4.14$, are higher than that of low attraction bird-watching tourists', which respectively are: 4.23, 4.36, 3.9. It can be seen from the previous analysis that bird-watching tourism is more attractive to low risk probability tourists than to low-attraction tourists. Therefore, by contrast, low risk tourists prefer to learn relevant knowledge about birdwatching, more consciously to protect birds and environment in the process of bird-watching. What's more, because of being interested in birding tourism, they will be more actively participate in related activities. On the topic of "I will donate money to support the ecological environment protection", low attraction bird-watching tourists have a higher average score than low-risk prospective bird tourists. This may be because the proportion of women in the low-attractiveness type (76.68\%) is much higher than the low-risk (52.78\%), women tend to spend more on emotional spending while men are more likely to donate rationally.

\section{Results and Implications}

The continuous development of wildlife tourism in China has brought about a series of positive economic, social and cultural effects, but it also has a great impact on the ecological environment and wildlife. Therefore, it is necessary to study the tourism psychology and behavior rules of wildlife tourists, and then segment the market of them, being good at the marketing and management of targeted group. Based on this, this study taking bird-watching tourists in Guangzhou as the research object, researched the involvement degree of birdwatching tourists to fractionize the market of bird-watching tourists, contribut- 
ing to understanding socio-demographic characteristics and responsible environmental behavior intentions of different types of tourists, and also being helpful to develop the corresponding marketing strategy and management system of different characteristics of different types of bird-watching tourists. The main conclusions and implications are as follows.

1) Referring from the related research results, such as Laurent and Kapferer (1985), McIntyre and Pigram (1992) and Hwang et al. (1999), as well as the combination of bird-watching tourism special situation, this study designed five dimension scale, including appeal, centricity, self-expression, risk possibility and risk consequences to measure the recreation involvement of bird-watching tourists. But the result of this study just had 4 factors, so this paper combined the two factors of "importance" and "pleasure" into "attraction" based on the definition of recreation involvement of McIntyre and Pigram (1992). Finally, this paper researched a local recreation involvement scale, which accorded with the background of Chinese bird-watching tourism, including four factors: Attractiveness, symbol, risk possibility and risk consequences to provide reference for the study of the concept, dimension constitution and scale design of recreation involvement.

2) Bird-watching tourists were divided into three different types of involvement through k-means cluster analysis. Moreover, through chi-square test, it found that different recreation involvement of bird-watching tourists had obvious differences in two aspects of social demographic characteristics, which were gender and age. Scholars such as Cook and Steward (1986) believed that women constituted the majority of eco-tourists. The results of this study also found that the number of women in the three categories was more than that of men, and the women with low attractiveness and high involvement were 1 - 2 times more than men, showing a significant difference. This showed that for a specific tourism activity, the interest and concerns of the eco-tourists are different. In bird-watching tourism, women are more concerned with the risk consequences of bird-watching, while men are more concerned with the attraction of bird watching. Therefore, in the process of marketing planning, relevant organizations and institutions can design some birding, photography contest, and bird-watching festival activities to enrich the content of bird-watching tourism products, thus in this way, the attraction of bird-watching tourism to male tourists is improved. Besides, under the premise of protecting ecotourism resources, relevant organizations and institutions can improve and add safety protection facilities and provide important information about forecasting of weather, birds and others to improve the security and comfortable experience of female tourists.

In terms of age, the interviewees are mostly young people aged between 18 and 25, and most of them are university students in Guangzhou. They are usually keen on bird-watching and environmental protection. And in terms of occupational characteristics, it can be seen that education workers and students ac- 
counted for $67.6 \%$. This is also in line with the current development of bird tourism in China. The Chinese birding was first initiated by the education worker Liao Xiaodong (Guangzhou middle school teacher). Over the past two decades, domestic bird-watching tourism activities have been carried out with the aim of enlightenment and education. In Guangzhou there are a lot of birdwatching institutions (such as bird-watching association, flight feather volunteer team, Xinhua study education institutions, and so on), they cooperate with some primary and middle school students to organize bird-watching tourism activities. In addition, Guangzhou government also regularly develop bird-watching games for primary and secondary students. Because of this, the development of bird-watching tourism in guangzhou is one of the best in China. This also provides some reference for the promotion of bird-watching tourism in other provinces and regions in China. Specifically, Scenic area managers can strengthen cooperation with these institutions, to hold some bird-watching activities. It not only can absorb a lots bird-watching tourists, but also can help the improvement of bird-watching tourist facilities in scenic spot, to achieve the goal of a win-win situation.

3) Previous studies have shown that tourists' recreation involvement affects the environment friendly behavior intention, in other words, tourists are involved in a particular tourism activities deeper, the implementation of environmental friendly behavior intention are stronger. Through single factor variance analysis method, this study also found that high involvement tourists had a big differences from the other two types of tourists on the environmental friendly behavior intention, to some extent also verifying scholars point of view. But are their environmental friendliness the same for travelers with similar levels of involvement? This study raised an objection to this. By k-means clustering analysis, it found that low risk and low attraction tourists had similar total average score, but their willingness in environmentally friendly behaviors existed significant differences by LSD test. The study found that low risk tourists preferred to go to learn the knowledge of protecting birds and their habitats $(\mathrm{p}=0.040<$ 0.050 ), paid more attention to not disturb birds and destroy the habitat of birds $(\mathrm{p}=0.022<0.050)$ than low attraction tourists, and also were more willing to participate in volunteer activities, maintain and promote the environment quality of scenic spots. However, it is more rational to donate to the ecological protection of the scenic spot. According to the demographic characteristics of the two types of tourists, this study thinks that because low risk tourists pay more attention to the attractiveness of bird-watching tourism activities, and low attraction tourists are more concerned about the risks of the consequences.

From this study, it is more clear about the direction of wildlife tourism research, that is the research of wildlife tourists is needed to deepen, the classification of the wildlife tourists and market segmentation has always been the focus of intense research. However, this paper explores factors influencing the environmental responsibility behavior of wildlife tourists only from the perspective 
of recreation involvement. But the environmental responsibility of wildlife tourists is also influenced by local attachment (Yu, 2015), visitor experience (Zhou, 2014), satisfaction (Dou, 2016), behavioral efficiency (Zhou, Li, \& Zhu, 2014), perceived value (Xia \& Chen, 2015) and so on. Therefore, it is necessary to consider more features and more situational factors in future research.

\section{References}

Ballantyne, R. et al. (2010). Visitors' Learning for Environmental Sustainability: Testing Short- and Long-Term Impacts of Wildlife Tourism Experiences using Structural Equation Modeling. Tourism Management, 19, 1-10.

Beh, A., \& Bruyere, B. L. (2007). Segmentation by Visitor Motivation in Three Kenyan National Reserves. Tourism Management, 28, 1464-1471.

https://doi.org/10.1016/j.tourman.2007.01.010

Chiu, Y.-T., Lee, W. L., \& Chen, T. H. (2014). Environmentally Responsible Behavior in Ecotourism: Antecedents and Implications. Tourism Management, 40, 321-329. https://doi.org/10.1016/j.tourman.2013.06.013

Christine, J. C., \& Bharath, J. (1995). Role of Involvement in the Travel Decision. Journal of Vacation Marketing, 1, 337-347. https://doi.org/10.1177/135676679500100403

Cong, L., Wu, B., \& Li, J. (2012). A Review of Foreign Wildlife Tourism. Journal of Tourism, 5, 57-65.

Dou, L. (2016). Tourists' Perceived Value, Satisfaction and Environmental Responsibility. Resources and Environment of Arid area, 30, 197-202.

Duffus, D. A., \& Dearden, P. (1990). Non-Consumptive Wildlife-Oriented Recreation: A Conceptual Framework. Biological Conservation, 53, 213-231.

https://doi.org/10.1016/0006-3207(90)90087-6

Havitz, M. E., \& Dimanche, F. (1997). Leisure Involvement Revisited: Conceptual Conundrums and Measurement Advances. Journal of Leisure Research, 29, 245-278. https://doi.org/10.1080/00222216.1997.11949796

Hwang, S. N., Lee, C., \& Chen, H. J. (2005). The Relationship among Tourists' Involvement, Place Attachment and Interpretation Satisfaction in Taiwan's National Parks. Tourism Management, 26, 143-156. https://doi.org/10.1016/j.tourman.2003.11.006

Kollmuss, A., \& Agyeman, J. (2002). Mind the Gap: Why Do People Act Environmentally and What Are the Barriers to Pro-Environmental Behavior? Environmental Education Research, 8, 239-260. https://doi.org/10.1080/13504620220145401

Laurent, G., \& Kapferer, J. (1985). Measuring Consumer Involvement Profiles. Journal of Marketing Research, 22, 41-53. https://doi.org/10.2307/3151549

Lee, T. H. (2011). How Recreation Involvement, Place Attachment, and Conservation Commitment affect Environmentally Responsible Behavior. Journal of Sustainable Tourism, 19, 895-915. https://doi.org/10.1080/09669582.2011.570345

Lee, W. H., \& Moscardo, G. (2005). Understanding the Impact of Ecotourism Resort Experiences on Tourists' Environmental Attitudes and Behavioural Intentions. Journal of Sustainable Tourism, 13, 546-565. https://doi.org/10.1080/09669580508668581

Lemelin, R. H., \& Smale, B. (2006). Effect of Environmental Context on the Experience of Polar Bear Viewers in Churchill, Manitoba. Journal of Ecotourism, 5, 176-191. https://doi.org/10.2167/joe142.0

Li, L., Wu, E., \& Ling, S. (2009). Analysis of Behavior Characteristics of Bird-Watching 
Tourists in Beijing. Journal of Harbin Commercial University (Social Science Edition), 1, 112-114.

Li, Q., \& Zhou, L. (2014). The Impact of Social Capital on the Willingness of Tourists to Conduct Friendly Behaviors. Tourism Journal, 9, 73-82.

Li, Y., \& Cai, Y. (2004). A Study on Ecotourists' Behavioral Characteristics in Beijing: A Case Study in Baihuashan Nature Reserve. Geographical Research, 6, 863-874.

Liu, J., Wang, H., \& Chen, R. (2009). Research on the Impact of Ecological Accommodation Experience and Personal Involvement on the Willingness of Tourists to Protect Their Environment. Tourism Journal, No. 8, 82-88.

Lubeck, L., \& Kusler, J. (1990) East African Safari Tourism. The Environmental Role of Tour Operators, Travel Agents and Tourists in Ecotourism and Resource Conservation: A Collection of Papers. Madison: Omni Press, 120-128.

McIntyre, N., \& Pigram, J. J. (1992). Recreation Specialization Reexamined: The Case of Vehicle-Based Campers. Leisure Research, 14, 3-15. https://doi.org/10.1080/01490409209513153

Park, M., Yang, X., Lee, B., Jang, H.-C., \& Stokowski, P. A. (2002). Segmenting Casino Gamblers by Involvement Profiles: A Colorado Example. Tourism Management, 23, 55-65. https://doi.org/10.1016/S0261-5177(01)00063-2

Rawles, C., \& Parsons, E. C. M. (2004). Environmental Motivation of Whale Watching Tourists in Scotland. Tourism in Marine Environments, 1, 129-132. https://doi.org/10.1086/208520

Selin, S. W., \& Howard, D. (1988). Ego-Involvement and Leisure Behavior: A Conceptual Specification. Journal of Leisure Research, 20, 237-244.

Thapa, B., Graefe, A. R., \& Meyer, L. A. (2008). Specialization and Marine Based Environmental Behavior among Scuba Divers. Journal of Leisure Research, 38, 601-615. https://doi.org/10.1080/00222216.2006.11950094

Xia, Z., \& Chen, S. (2015). The Influence of Eco-Tourists' Perceived Value on Environmental Friendly Behavior Intention. Journal of Zhongnan University of Forestry and Technology (Social Science Edition), 9, 27-32 + 77.

Yu, J. (2015). Study on the Relationship between Ecological Tourism Involvement, Local Attachment and Environmental Responsibility. Hangzhou: Zhejiang University.

Zaichkowsky, J. L. (1985). Measuring the Involvement Construct. Journal of Consumer Research, 3, 341-352. https://doi.org/10.1086/208520

Zeng, F., Luo, Y., Bi, H., \& Zhao, Z. (2014). Ecological Tourists: Discrimination and Environmental Friendly Behavioral Intention. Economic Geography, 6, 182-186 + 192.

Zhang, A., \& Li, Y. (2016). Research on the Influence of Leisure Involvement on the Environmental Behavior of Tourists in the Context of Local Attachment. Journal of Central South University of Forestry Science and Technology (Social Sciences Edition), 1, 70-78.

Zhang, H., \& Lu, L. (2010). The Comparison of Tourists' Influence on the Image Perception of Tourism Destination and the Comparison of the Anglu Inbound Tourists and Domestic Tourists. Journal of Geography, 12, 1613-1623.

Zhou, L.-Q., Li, Q., \& Zhu, L. (2014). Environmentally Responsible Behavior Performance, Emotion to People and Tourists Behavior Intention: An Improved Model Based on the Theory of Planned Behavior. Journal of Zhejiang University (Humanities and Social Science Edition), 44, 88-98. 